\title{
Influence Of Different Irrigant Activation Techniques In Post - Operative Endodontic Pain - A Review Of Literature
}

Research Article

\section{Nivedhitha ${ }^{1 *}$, Swarna $^{2}$}

${ }^{1}$ Professor and Head, Department of Conservative Dentistry and Endodontics, Saveetha Dental College and Hospitals, Saveetha Institute of Medical and Technical Sciences, Saveetha University, Chennai, India.

${ }^{2}$ Department of Conservative Dentistry \& Endodontics, Saveetha Dental College and Hospitals, Saveetha Institute of Medical and Technical Sciences, Saveetha University, Chennai, India.

\section{Abstract}

Introduction: Pain management during endodontic therapy has been a major concern among the dentists since many years. Patients often associate endodontic treatment with pain. The incidence of post - operative pain following root canal treatment is in the range of $3-58 \%[1,2]$. This review of literature analyzes the various irrigant activation techniques and their effectiveness in pain management.

Materials and Methods: A search was performed in electronic database (i.e. PUBMED CENTRAL, Google and Hand Search) using following search terms alone and in combination by means of PUBMED search builder till March 2021. The various irrigant activation techniques were reviewed and all randomized clinical trials evaluating post operative pain following endodontic irrigation were analyzed.

Results: Randomised clinical trials using irrigation activation techniques resulted in lesser post operative pain then conventional needle irrigation. Though manual dynamic agitation was capable of removing the vapor lock effect, it still had the tendency to push the irrigant beyond apex resulting in increased postoperative pain compared to other irrigation techniques. Conclusion: All the clinical studies concluded that irrigant activation with sonic, ultrasonic, laser activated irrigation and manual dynamic agitation produced lesser post operative pain. EndoVac which is a negative pressure irrigation system also proves to be better than conventional needle irrigation in terms of post operative pain.

Keywords: Conventional Irrigation; Irrigant Activation; Laser Activated Irrigation; Post Operative Pain; Sonic Irrigation; Ultrasonic Irrigation.

\section{Introduction}

Post operative pain is an undesirable occurrence in endodontics. Understanding the frequency of occurrence of post endodontic pain in vital, non vital or necrotic teeth and the contributing etiological factors would enable the clinician to effectively manage the post operative pain. Effective pain management is the primary requisite in Endodontic therapy. Art of anesthetizing the tooth with proper techniques and informing the patients to expect a significant amount of pain can increase the pain threshold of the patient as well as gain confidence to undergo root canal treatment [3]. The frequency of post endodontic pain was in the range of 1.5 to $53 \%[4]$.

Single visit root canal treatment for vital teeth has advantages such as reduced flare up rate, decreased number of operative procedures, no risk of interappointment leakage through temporary restorations, patient acceptance and reduced post operative pain [5]. A systematic review by Figini et al concluded that patients undergoing a single visit might experience a slightly higher fre-

\section{*Corresponding Author}

Nivedhitha,

Professor and Head, Department of Conservative Dentistry and Endodontics, Saveetha Dental College and Hospitals, Saveetha Institute of Medical and Technical Sciences, Saveetha University, Chennai, India.

Email Id: nivedhitha.sdc@saveetha.com

Received: April 28, 2021

Accepted: May 28, 2021

Published: May 30, 2021

Citation: Nivedhitha, Swarna. Influence Of Different Irrigant Activation Techniques In Post - Operative Endodontic Pain - A Review Of Literature. Int J Dentistry Oral Sci. 2021;08(05):2659-2665. doi: http://dx.doi.org/10.19070/2377-8075-21000520

Copyright: Nivedhitha ${ }^{\circ}$ 2021. This is an open-access article distributed under the terms of the Creative Commons Attribution License, which permits unrestricted use, distribution and reproduction in any medium, provided the original author and source are credited. 
quency of swelling and refer significantly more analgesic use [6]. Difficulty in accessing the canal apex in acute curvatures, canal transportation or over instrumentation, extended operating time, inadequate contact time of irrigants, lack of placing intracanal medicament may be some of the reasons for failures or flare ups following single visit endodontic treatment [7].

There are studies that analyzed the factors contributing for pain in endodontics such as age, gender, tooth arch, tooth type or location, presence and severity of preoperative pain, pulpal status, presence and size of periapical lesion, number of root canals present, intracanal irrigant and medicament used, presence of interappointment pain, extent of root filling, single visit versus multiple visit root canal procedures have been investigated in some studies $[1,8]$. Occlusal reduction done during initiation of endodontic therapy has influenced reduction of pain of mandibular molars with symptomatic irreversible pulpitis [9].

Previously our team has a rich experience in working on various research projects across multiple disciplines [10-24]. Now the growing trend in this area motivated us to pursue this project.

\section{Pain In Endodontics}

Extrusion of microbes and debris is not uncommon during the canal cleaning, shaping or filing procedures aggravates the inflammatory response and causes periradicular inflammation. The Postendodontic pain most often occurs during the first 24 to 48 hours after obturation, although it occasionally persists for several days [4].

Pak et al, 2011 suggested that the prevalence of pretreatment root canal associated pain was high within 1 day and continued to drop to minimal levels in 7 days $[25,26]$. Factors that were found to be significantly associated with pain or discomfort included younger age, gender, tenderness to percussion, and tenderness on apical palpation [27].

Operator errors such as violating the apical constriction due to over instrumentation, apicoectomy, perforation, forceful irrigation are contributing factors for irrigant or debris extrusion which initiates the post operative pain [28, 29].

\section{Significance Of Irrigation Dynamics In Endodontic Disin- fection}

The disinfection of the root canal system comprises mechanical cleaning and shaping using hand and rotary files augmented by use of chemical irrigants capable of effectively removing microorganisms, biofilm and smear layer from the areas inaccessible to instrumentation. The root canal system has a complex anatomy with lateral canals, fins, isthmuses, apical delta, ramifications, C shaped canals and oval canals [30]. The smear layer formed after instrumentation serves as a niche for microorganisms. The mechanism of action of the irrigant as well as the mode of delivery plays a crucial role in removing the microbes and smear layer.

Sodium hypochlorite is the only irrigant capable of pulp tissue dissolution used in concentrations of $0.5-6 \%$ [31]. The antimicrobial and tissue dissolving ability of sodium hypochlorite is attributed to chlorine, which is unstable and dissipated rapidly during tissue dissolution [32]. The effectiveness of tissue dissolu- tion can be safely increased by frequent replenishment and activation of the irrigant $[33,34]$. Studies have shown that use of hypochlorite after smear removal by EDTA, can cause erosion on dentin [35]. Also chlorhexidine reacts with hypochlorite leading to a carcinogenic precipitate called para-chloroaniline (PCA) [36]. Saline can be used in between two irrigants to avoid the chemical reaction. 17\% EDTA is used as a final irrigant and it removes the inorganic smear layer containing debris, microbes and microbial products [37].

Thus an ideal effective concentration of irrigant, contact time and penetration of irrigant should be enhanced by activation techniques to improve clinical success rates of endodontic treatment [38]. $5.25 \% \mathrm{NaOCl}$ was associated with significantly lower postoperative pain compared to $2.5 \% \mathrm{NaOCl}$ during the first $72 \mathrm{~h}$ following one-visit root canal treatment of mandibular molars with irreversible pulpitis which might be due effective pulp dissolution [39].

\section{Conventional Needle Irrigation}

Mechanical instrumentation alone would not be sufficient to reach the complex root canal intricacies such as isthumes, c shaped canals, fins, lateral and accessory canals. Hence effective endodontic irrigants such as sodium hypochlorite for pulp tissue removal as well as EDTA for effective debris removal are used along with irrigant activation techniques in order to achieve maximum effectiveness by improved contact between root canal walls and the irrigant used.

Irrigant activation helps in effective removal of bacteria, debris, smear layer and significantly improves irrigant penetration [40]. Studies have proved that in oval canals, only $40 \%$ of the apical root canal wall area comes in contact with rotary instruments [41].

An apical preparation size of $0.3 \mathrm{~mm}$ was suggested for effective irrigant penetration in the apical third [42]. Computational fluid dynamics (CFD) studies simulate irrigant flow in a root canal model and evaluate parameters such as canal taper, apical pressure and irrigant exchange at the apical third of the root because of the forces exerted by irrigant flow [43]. These studies affirmed that the irrigant replacement was limited to $1-1.5 \mathrm{~mm}$ apical to the needle tip. Low-Reynolds number turbulent flow was detected near the needle outlet $[43,44]$. The flow of irrigant and its replenishment is critical for improving the effective contact time of irrigant with the root canal walls $[45,46]$.

Size 27-gauge or 30-gauge needles facilitated better irrigant penetration up to the apical third of the root canal [47]. Side-vented needles (tip) may offer safer irrigation than open-ended needles in positive pressure irrigation [48]. Activation of the irrigant and constant replenishment improves the efficacy of irrigant [49].

Post operative pain following conventional needle irrigation was greater than negative pressure irrigation [50], sonic irrigation [51] and ultrasonic irrigation [52]. During conventional needle positive pressure irrigation, there are increased chances of extrusion of irrigating solutions showing varying degrees of cytotoxicity. Immediate long lasting pain occurs when sodium hypochlorite is expressed under pressure and then escapes through the apical foramen. The incidence of post- operative pain is upto $30 \%$ [2]. 
The reasons for irrigant extrusion were high flow rate, destruction of the apical constriction, over-instrumentation, perforation of the root canal system, root resorption, wedging of the needle in the root canal, presence of a periapical lesion and horizontal root fracture [53].

\section{Techniques Of Irrigant Activation}

- Manual Dynamic Activation (MDA).

- Sonic irrigant activation.

- Passive Ultrasonic Irrigation.

- Continuous Ultrasonic Irrigation.

- Laser activated irrigation.

Manual Dynamic Agitation (MDA): Manual dynamic agitation technique uses the master cone in an instrumented, irrigant filled canal. The master cone is placed $1 \mathrm{~mm}$ short of working length and activated in up and down motion with $2 \mathrm{~mm}$ amplitude and frequency of 100 strokes per minute [54]. This technique was very effective in avoiding the vapour lock effect caused by sodium hypochlorite [55]. The technique was dependent on operator and could not be standardized and frequency of irrigant extrusion was more that led to post operative pain $[53,52]$.

Neelakantan et al did histological assessment of debridement of the root Canal Isthmus of mandibular molars by irrigant activation techniques and concluded that MDA showed significantly less remaining pulpal tissues at 1 and $3 \mathrm{~mm}$ from the apex compared with PUI and syringe irrigation [56]. Topcuoglu et al studied that the post operative pain in mandibular molars with symptomatic irreversible pulpitis was greater with MDA during first 24 hours as compared to sonic and ultrasonic irrigation [52] (Table 1).

Ultrasonic Irrigation: In 1957, Richman first introduced ultrasonic devices in Endodontics. Passive ultrasonic irrigation was first described by Weller et al in 1980 and refers to the 'noncutting' action of the ultrasonically activated file. Roy et al stated that two types of activation can occur during Passive ultrasonic irrigation in root canals namely stable and transient [57]. $40 \mathrm{kHz}$ cycles are produced per second and the piezoelectric tips work in a linear movement from back to front like a piston and is ideal for endodontic treatment [58]. The ultrasonic tips do not rotate, and high cutting efficiency obtained with excellent safety and control.

Passive Ultrasonic Irrigation (PUI) that firstly delivers the irrigant solution in to the root canal and then introduces the ultrasonic tip, without touching the canal walls. Continuous Ultrasonic Irrigation (CUI), where the activation of the irrigant solution is performed simultaneously with its delivery into the canal. The phenomena of acoustic streaming happens due to vibration of the ultrasonic tips that generates shear stress which dislodges the debris from the canal. Ultrasonic waves are able to propagate inside the irrigant solution and to create microcavitation (small voids) that implode, shaking the solution inside the canal and improving the removal of the smear layer as well as improving the penetration of the liquid in to the apical third of the root canal system.

Dioguardi et al, 2019 concluded from his systematic review that
PUI is more effective in vapor lock removal than conventional needle irrigation [59]. Nagendrababu et al did a systematic review of in vitro studies and concluded that PUI resulted in better disinfection of the root canal system than conventional needle irrigation [60]. Studies comparing post operative pain levels following continuous ultrasonic irrigation [61] and passive ultrasonic irrigation $[52,62]$ have reported lesser pain score than conventional needle irrigation (Table-1).

Laser Activated Irrigation: Laser light can penetrate areas of canals where irrigating and disinfecting solutions cannot reach, such as fins, deltas, and lateral canals. Selective photothermolysis occurs when laser energy is applied into the root canal system. The lasers used most commonly for photothermal disinfection are the Nd:YAG, KTP and near-infrared diode lasers. Er YSGG laser has several applications in conventional endodontics namely Biofilm preconditioning, Cleaning and disinfection, Recapitulation, achieving Patency and Drainage and decompression.

Laser Assisted Disinfection Of Root Canals: Laser targets the cell wall of bacteria and leads to swelling due to changes in osmotic gradient leading to cellular death. Photosensitizer substances, such as methylene blue (MB), toluidine blue (TB) sensitizes the bacteria to diode light resulting in the production of singlet oxygen. The laser-induced morphological effects on root canal walls due to thermal effects that were sufficient to remove smear layer and debris without causing any carbonization and melting [63].

Effect Of Laser On Endodontic Irrigants: Pulsed erbium lasers had a thermal effect and caused expansion and successive vapor bubble implosion with in irrigant generating a high speed movement of fluid through a cavitation effect. The thermal effect caused by lasers leads to expansion and successive vapor bubble implosion with in irrigant fluids that creates a secondary cavitation effect on the intracanal irrigants. The canal preparation was more smooth following the laser activation of irrigants.

Laser Irrigation Techniques In Endodontics: Traditional laser endodontics (direct laser irradiation) involves the use of endfiring tips or fibers, positioned $1 \mathrm{~mm}$ short of working length and irradiated while with drawing the fiber from the canal [64].

Photo-activated disinfection (PAD), photodynamic therapy, or light-activated disinfection (LAD) requires the use of different photosensitizers with antimicrobial activity that are selectively activated by different wave lengths.

Laser-activated irrigation (LAI) and Photon induced photoacoustic streaming (PIPS) involves the use of radial-firing tips to improve the lateral emission of photons to activate the irrigants [65].

SWEEPS protocol (shock wave-enhanced emission photoacoustic streaming).

PIPS works at low energy levels from $50 \mathrm{~mJ}$ to $20 \mathrm{~mJ}$ at 10 to 15 $\mathrm{Hz}$ with short pulses around 50 microseconds to generate shock waves [66]. Effective smear layer removal was observed with PIPS than syringe irrigation and effective bacterial reduction seen when PIPS was used in conjunction with $6 \%$ sodium hypochlorite [67].

In the SWEEPS technique, a pair of individual laser pulses are emitted at time T0, and the initial vapor bubble and smaller sec- 
Table 1. Randomised clinical trials evaluating post operative pain following Irrigant activation.

\begin{tabular}{|c|c|c|c|c|}
\hline S.no & Author/ year & Intervention & Comparison & Outcome (Post op pain reduction) \\
\hline 1 & Al-zaka, 2012 & $\begin{array}{l}\text { Endoactivator(EA) } \\
\text { Safety irrigator }\end{array}$ & Needle irrigation & $\mathrm{EA}>\mathrm{EN}$ \\
\hline 2 & $\begin{array}{l}\text { Ramamoorthi, } \\
2015\end{array}$ & Endoactivator(EA) & $\begin{array}{l}\text { Endodontic } \\
\text { needle }\end{array}$ & $\mathrm{EA}>\mathrm{EN}$ \\
\hline 3 & Middha, 2017 & $\begin{array}{c}\text { Continuous ultrasonic } \\
\text { irrigation }\end{array}$ & Needle irrigation & Ultrasonic $>$ needle \\
\hline 4 & Topcuoglu, 2018 & $\begin{array}{l}\text { Negative pressure } \\
\text { irrigation(NPI) } \\
\text { (EndoVac) }\end{array}$ & $\begin{array}{l}\text { Positive pressure } \\
\text { irrigation } \\
(\mathrm{PPI})\end{array}$ & $\mathrm{NPI}>\mathrm{PPI}$ \\
\hline 5 & Topcuoglu, 2018 & $\begin{array}{c}\text { Sonic irrigation(SI) } \\
\text { Ultrasonic } \\
\text { irrigation(PUI) }\end{array}$ & $\begin{array}{c}\text { Manual Dynamic } \\
\text { agitation } \\
\text { (MDA) }\end{array}$ & $\mathrm{SI}=\mathrm{UI}>\mathrm{MDA}$ \\
\hline 6 & Morsy, 2018 & DIODE laser & $\begin{array}{l}\text { Endodontic } \\
\text { needle }\end{array}$ & Diode $>$ EN \\
\hline 7 & Dagher, 2019 & Er: YAG & $\begin{array}{l}\text { Endodontic } \\
\text { needle }\end{array}$ & Er: YAG> EN \\
\hline 8 & Yilmaz, 2019 & EndoActivator(EA) & $\mathrm{CNI}$ & $\mathrm{EA}>\mathrm{EN}$ \\
\hline 9 & Gundogar, 2020 & Sonic, Ultrasonic, & $\mathrm{CNI}$ & Sonic $>$ Ultrasonic $>$ EN \\
\hline 10 & Mandras, 2020 & Er:YAG & $\begin{array}{l}\text { Endodontic } \\
\text { needle }\end{array}$ & Er: YAG> EN \\
\hline 11 & Liapis, 2021 & Er: YAG & $\begin{array}{c}\text { Ultrasonic irriga- } \\
\text { tion }\end{array}$ & Er: YAG=UI \\
\hline
\end{tabular}

ondary vapor bubbles are simultaneously formed at the fiber tip. The pressure waves created by these bubbles induce the violent collapse of the initial and secondary bubbles amplifies the effect of photoacoustic streaming within the root canal system [68-70].

The Nd:YAG laser and the erbium laser family emit energy in a "pulsed" mode and thermal relaxation time allows the surface to cool. Erbium lasers with "end-firing" tips, with frontal emission at the end of the tip, have little lateral penetration of the dentinal wall, so that a radial-emitting tip was proposed in 2007 for the Er, Cr:YSGG laser [71].

The canals should be prepared up to apical preparation with ISO 25/30) for Nd:YAG and erbium lasers, to facilitate placement of optical fibre of $200 \mu \mathrm{m}$ diameter, $1 \mathrm{~mm}$ short of working length and retracted with a helical movement in five to ten seconds. Previously it was used in dry canals but recent studies emphasize the presence of irrigant to avoid thermal damage to the tooth and improve the antimicrobial effect on biofilms [72].

Radial firing tips work at clinically safe temperatures and act laterally on the dentinal walls avoiding hazardous effect on periapical tissues. It enables dislodgement of the biofilm. The phenomena of vapor lock effect is also effectively eliminated by the radial firing tips thus improving the penetration of irrigant at the apical third.

Jaramillo stated that activation of a buffered $0.5 \%$ sodium hypochlorite solution by PIPS (photon induced photoacoustic streaming significantly increased its antimicrobial capacity compared to conventional irrigation $[73,68]$. Kosarieh et al studied the Effect of Er:YAG laser irradiation using SWEEPS and PIPS technique on dye penetration depth after root canal preparation and concluded the conventional and Sweeps technique provided similar results, where as PIP had more effective penetration in to dentinal tubules [74]. The amount of irrigant extrusion following conventional needle irrigation was greater than laser activated irrigation with radial firing tips and PIPS [75]. Post operative pain following Er. YAG( PIPS) [76] and DIODE laser [77] have shown improved pain reduction compared to conventional needle irrigation and similar results as passive ultrasonic irrigation [78] (Table 1). Photodynamic therapy showed a significant amount of post operative pain reduction with methylene blue and $3 \mathrm{~min}$ irradiation with soft tissue laser [79].

\section{Discussion}

Gulabivala studied the fluid mechanics of root canal irrigation and concluded that the use of side-opening needles may be more effective than end-opening needles because the Reynolds number is higher at the exit of the side opening of a needle tip and the shear stress opposite the outlet much higher than for other needle designs [80]. Needles with multiple openings around the circumference of the needle may provide a means to improve biofilm removal. The reciprocating action of a well-fitting cone not only enhances mixing of the fluid in the canal but also increases significantly the shear stress on the canal wall and eliminates vapor lock effect due to gas bubbles [81]. Sonic or ultrasonic agitation of the fluid through unconstrained file oscillation can generate large shear stresses on the canal surface and streaming flow inside the root canal [80].

Limitations of the studies were differences in the inclusion criteria or clinical conditions chosen for the study. Some of the clinical 
trials have studied asymptomatic cases to check for incidence of pain following irrigant activation, where as few cases had chosen symptomatic cases to check for pain reduction. The concentration of irrigants used, the combination of irrigants, the needle gauge sizes, the depth of penetration varied among different studies. Our institution is passionate about high quality evidence based research and has excelled in various fields [14, 82-91]. Hence more randomised clinical trials with stringent criteria must be carried out to arrive at definitive conclusions regarding the most appropriate technique of irrigant activation.

\section{Acknowledgement and Declaration}

We would like to acknowledge my mentors and guide for helping me in data collection and analysis and better understanding of the subject. We declare that the systematic search was performed and detailed assessment of studies done to arrive at clinically relevant solutions.

\section{Conclusion}

Based on available literature, Irrigant activation techniques experienced significantly less amount of postoperative pain compared to conventional needle irrigation. Laser activated irrigation using erbium lasers and passive ultrasonic irrigation techniques have shown similar results for pain reduction. Further clinical trials with standardized protocols will aid in painless and effective, evidence based irrigant activation techniques.

\section{References}

[1]. Sadaf D, Ahmad MZ. Factors associated with postoperative pain in endodontic therapy. Int J Biomed Sci. 2014 Dec;10(4):243-7. Pubmed PMID: 25598754

[2]. Sathorn C, Parashos P, Messer H. The prevalence of postoperative pain and flare-up in single- and multiple-visit endodontic treatment: a systematic review. Int Endod J. 2008 Feb;41(2):91-9. Pubmed PMID: 17956561.

[3]. Gotler M, Bar-Gil B, Ashkenazi M. Postoperative pain after root canal treatment: a prospective cohort study. Int J Dent. 2012;2012:310467. Pubmed PMID: 22505897

[4]. Philpott R, Gulabivala K, Leeson R, Ng YL. Prevalence, predictive factors and clinical course of persistent pain associated with teeth displaying periapical healing following nonsurgical root canal treatment: a prospective study. Int Endod J. 2019 Apr;52(4):407-415. Pubmed PMID: 30332512.

[5]. Schwendicke F, Göstemeyer G. Single-visit or multiple-visit root canal treatment: systematic review, meta-analysis and trial sequential analysis. BMJ Open. 2017 Feb 1;7(2):e013115. Pubmed PMID: 28148534.

[6]. Figini L, Lodi G, Gorni F, Gagliani M. Single versus multiple visits for endodontic treatment of permanent teeth: a Cochrane systematic review. J Endod. 2008 Sep;34(9):1041-7. Pubmed PMID: 18718362.

[7]. Manfredi M, Figini L, Gagliani M, Lodi G. Single versus multiple visits for endodontic treatment of permanent teeth. Cochrane Database Syst Rev. 2016 Dec 1;12(12):CD005296. Pubmed PMID: 27905673.

[8]. Nagendrababu V, Gutmann JL. Factors associated with postobturation pain following single-visit nonsurgical root canal treatment: A systematic review. Quintessence Int. 2017;48(3):193-208. Pubmed PMID: 27669726.

[9]. Ahmed YE, Emara RS, Sarhan SM, El Boghdadi RM, El-Bayoumi MAA, El-Far HMM, et al. Post-treatment endodontic pain following occlusal reduction in mandibular posterior teeth with symptomatic irreversible pulpitis and sensitivity to percussion: a single-centre randomized controlled trial. Int Endod J. 2020 Sep;53(9):1170-1180. Pubmed PMID: 32418236.

[10]. Govindaraju L, Gurunathan D. Effectiveness of Chewable Tooth Brush in Children-A Prospective Clinical Study. J Clin Diagn Res. 2017 Mar;11(3):ZC31-ZC34. Pubmed PMID: 28511505.

[11]. Christabel A, Anantanarayanan P, Subash P, Soh CL, Ramanathan M, Muthusekhar MR, et al. Comparison of pterygomaxillary dysjunction with tuberosity separation in isolated Le Fort I osteotomies: a prospective, multi-centre, triple-blind, randomized controlled trial. Int J Oral Maxillofac Surg. 2016
Feb;45(2):180-5. Pubmed PMID: 26338075.

[12]. Soh CL, Narayanan V. Quality of life assessment in patients with dentofacial deformity undergoing orthognathic surgery--a systematic review. Int J Oral Maxillofac Surg. 2013 Aug;42(8):974-80. Pubmed PMID: 23702370.

[13]. Mehta M, Deeksha, Tewari D, Gupta G, Awasthi R, Singh H, et al. Oligonucleotide therapy: An emerging focus area for drug delivery in chronic inflammatory respiratory diseases. Chem Biol Interact. 2019 Aug 1;308:206215. Pubmed PMID: 31136735.

[14]. Ezhilarasan D, Apoorva VS, Ashok Vardhan N. Syzygium cumini extract induced reactive oxygen species-mediated apoptosis in human oral squamous carcinoma cells. J Oral Pathol Med. 2019 Feb;48(2):115-121. Pubmed PMID: 30451321.

[15]. Campeau PM, Kasperaviciute D, Lu JT, Burrage LC, Kim C, Hori M, et al. The genetic basis of DOORS syndrome: an exome-sequencing study. Lancet Neurol. 2014 Jan;13(1):44-58. Pubmed PMID: 24291220.

[16]. Kumar S, Sneha S. Knowledge and awareness regarding antibiotic prophylaxis for infective endocarditis among undergraduate dental students. Asian Journal of Pharmaceutical and Clinical Research. 2016;154.

[17]. Christabel SL, Gurunathan D. Prevalence of type of frenal attachment and morphology of frenum in children, Chennai, Tamil Nadu. World J Dent. 2015 Oct;6(4):203-7.

[18]. Kumar S, Rahman RE. Knowledge, awareness, and practices regarding biomedical waste management among undergraduate dental students. Asian Journal of Pharmaceutical and Clinical Research. 2017;10(8):341.

[19]. Sridharan G, Ramani P, Patankar S. Serum metabolomics in oral leukoplakia and oral squamous cell carcinoma. J Cancer Res Ther. $2017 \mathrm{Jul}-$ Sep;13(3):556-561. Pubmed PMID: 28862226.

[20]. Ramesh A, Varghese SS, Doraiswamy JN, Malaiappan S. Herbs as an antioxidant arsenal for periodontal diseases. J Intercult Ethnopharmacol. 2016 Jan 27;5(1):92-6. Pubmed PMID: 27069730.

[21]. Thamaraiselvan M, Elavarasu S, Thangakumaran S, Gadagi JS, Arthie T. Comparative clinical evaluation of coronally advanced flap with or without platelet rich fibrin membrane in the treatment of isolated gingival recession. J Indian Soc Periodontol. 2015 Jan-Feb;19(1):66-71. Pubmed PMID: 25810596.

[22]. Thangaraj SV, Shyamsundar V, Krishnamurthy A, Ramani P, Ganesan K, Muthuswami M, et al. Molecular Portrait of Oral Tongue Squamous Cell Carcinoma Shown by Integrative Meta-Analysis of Expression Profiles with Validations. PLoS One. 2016 Jun 9;11(6):e0156582. Pubmed PMID: 27280700.

[23]. Ponnulakshmi R, Shyamaladevi B, Vijayalakshmi P, Selvaraj J. In silico and in vivo analysis to identify the antidiabetic activity of beta sitosterol in adipose tissue of high fat diet and sucrose induced type- 2 diabetic experimental rats. Toxicol Mech Methods. 2019 May;29(4):276-290. Pubmed PMID: 30461321.

[24]. Ramakrishnan M, Bhurki M. Fluoride, Fluoridated Toothpaste Efficacy And Its Safety In Children-Review. International Journal of Pharmaceutical Research. 2018 Oct 1;10(04):109-14.

[25]. Pak JG, White SN. Pain prevalence and severity before, during, and after root canal treatment: a systematic review. J Endod. 2011 Apr;37(4):429-38. Pubmed PMID: 21419285.

[26]. Azarpazhooh A, Shah PS. Nonsurgical root canal treatment may reduce the prevalence and severity of pain of endodontic origin within 1 day following treatment and substantially to minimal levels in 7 days. J Evid Based Dent Pract. 2012 Mar;12(1):12-3. Pubmed PMID: 22326150.

[27]. Long-term pain after root canal treatment (2020). Vol. 65, Dental Abstracts. p. 150.

[28]. Ricucci D, Langeland K. Apical limit of root canal instrumentation and obturation, part 2. A histological study. Int Endod J. 1998 Nov;31(6):394-409. Pubmed PMID: 15551607.

[29]. Estrela C, Pécora JD, Estrela CRA, Guedes OA, Silva BSF, Soares CJ, et al. Common Operative Procedural Errors and Clinical Factors Associated with Root Canal Treatment. Braz Dent J. 2017 Jan-Apr;28(2):179-190. Pubmed PMID: 28492747.

[30]. Haapasalo M, Shen Y, Qian W, Gao Y. Irrigation in endodontics. Dent Clin North Am. 2010 Apr;54(2):291-312. Pubmed PMID: 20433979.

[31]. Siqueira JF Jr, Rôças IN, Favieri A, Lima KC. Chemomechanical reduction of the bacterial population in the root canal after instrumentation and irrigation with $1 \%, 2.5 \%$, and 5.25\% sodium hypochlorite. J Endod. 2000 Jun;26(6):331-4. Pubmed PMID: 11199749.

[32]. Moorer WR, Wesselink PR. Factors promoting the tissue dissolving capability of sodium hypochlorite. Int Endod J. 1982 Oct;15(4):187-96. Pubmed PMID: 6964523.

[33]. Basrani B, Haapasalo M. Update on endodontic irrigating solutions. Endodontic topics. 2012 Sep;27(1):74-102.

[34]. Basrani B, Malkhassian G. Update of endodontic irrigating solutions. InEndodontic Irrigation 2015 (pp. 99-115). Springer, Cham. 
[35]. Qian W, Shen Y, Haapasalo M. Quantitative analysis of the effect of irrigant solution sequences on dentin erosion. J Endod. 2011 Oct;37(10):1437-41. Pubmed PMID: 21924198

[36]. Basrani BR, Manek S, Sodhi RN, Fillery E, Manzur A. Interaction between sodium hypochlorite and chlorhexidine gluconate. J Endod. 2007 Aug;33(8):966-9. Pubmed PMID: 17878084.

[37]. Haapasalo M, Qian W, Shen Y. Irrigation: beyond the smear layer. Endodontic Topics. 2012 Sep;27(1):35-53

[38]. Moazami F, Sahebi S, Sobhnamayan F, Alipour A. Success rate of nonsurgical endodontic treatment of nonvital teeth with variable periradicular lesions. Iran Endod J. 2011 Summer;6(3):119-24. Pubmed PMID: 23130063.

[39]. Farzaneh S, Parirokh M, Nakhaee N, Abbott PV. Effect of two different concentrations of sodium hypochlorite on postoperative pain following singlevisit root canal treatment: a triple-blind randomized clinical trial. Int Endod J. 2018 Jan;51 Suppl 1:e2-e11. Pubmed PMID: 28134983.

[40]. Gu LS, Kim JR, Ling J, Choi KK, Pashley DH, Tay FR. Review of contemporary irrigant agitation techniques and devices. J Endod. 2009 Jun;35(6):791804. Pubmed PMID: 19482174.

[41]. Wu MK, Wesselink PR. A primary observation on the preparation and obturation of oval canals. Int Endod J. 2001 Mar;34(2):137-41. Pubmed PMID: 11307262.

[42]. Boutsioukis C, Lambrianidis T, Vasiliadis L. Clinical relevance of standardization of endodontic irrigation needle dimensions according to the ISO 9,626:1991 and 9,626:1991/Amd 1:2001 specification. Int Endod J. 2007 Sep;40(9):700-6. Pubmed PMID: 17645515.

[43]. Boutsioukis C, Gogos C, Verhaagen B, Versluis M, Kastrinakis E, Van der Sluis LW. The effect of root canal taper on the irrigant flow: evaluation using an unsteady Computational Fluid Dynamics model. Int Endod J. 2010 Oct;43(10):909-16. Pubmed PMID: 20618877.

[44]. Boutsioukis C, Lambrianidis T, Kastrinakis E. Irrigant flow within a prepared root canal using various flow rates: a Computational Fluid Dynamics study. Int Endod J. 2009 Feb;42(2):144-55. Pubmed PMID: 19134043

[45]. Boutsioukis C, van der Sluis LW. Syringe irrigation: blending endodontics and fluid dynamics. InEndodontic Irrigation 2015 (pp. 45-64). Springer, Cham

[46]. Salzgeber RM, Brilliant JD. An in vivo evaluation of the penetration of an irrigating solution in root canals. J Endod. 1977 Oct;3(10):394-8. Pubmed PMID: 270543.

[47]. Gopikrishna V, Sibi S, Archana D, Pradeep Kumar AR, Narayanan L. An in vivo assessment of the influence of needle gauges on endodontic irrigation flow rate. J Conserv Dent. 2016 Mar-Apr;19(2):189-93. Pubmed PMID: 27099430.

[48]. Park E, Shen Y, Khakpour M, Haapasalo M. Apical pressure and extent of irrigant flow beyond the needle tip during positive-pressure irrigation in an in vitro root canal model. J Endod. 2013 Apr;39(4):511-5. Pubmed PMID: 23522547.

[49]. Stojicic S, Zivkovic S, Qian W, Zhang H, Haapasalo M. Tissue dissolution by sodium hypochlorite: effect of concentration, temperature, agitation, and surfactant. J Endod. 2010 Sep;36(9):1558-62. Pubmed PMID: 20728727.

[50]. Gondim E Jr, Setzer FC, Dos Carmo CB, Kim S. Postoperative pain after the application of two different irrigation devices in a prospective randomized clinical trial. J Endod. 2010 Aug;36(8):1295-301. Pubmed PMID: 20647083

[51]. Ramamoorthi S, Nivedhitha MS, Divyanand MJ. Comparative evaluation of postoperative pain after using endodontic needle and EndoActivator during root canal irrigation: A randomised controlled trial. Aust Endod J. 2015 Aug;41(2):78-87. Pubmed PMID: 25195661.

[52]. Topçuoğlu HS, Topçuoğlu G, Arslan H. The Effect of Different Irrigation Agitation Techniques on Postoperative Pain in Mandibular Molar Teeth with Symptomatic Irreversible Pulpitis: A Randomized Clinical Trial. J Endod. 2018 Oct;44(10):1451-1456. Pubmed PMID: 30144989.

[53]. Boutsioukis C, Psimma Z, van der Sluis LW. Factors affecting irrigant extrusion during root canal irrigation: a systematic review. Int Endod J. 2013 Jul;46(7):599-618. Pubmed PMID: 23289914

[54]. Machtou PP. Manual dynamic activation technique. Clinical Dentistry Reviewed. 2018 Nov;2(1):1-5

[55]. Tay FR, Gu LS, Schoeffel GJ, Wimmer C, Susin L, Zhang K, et al. Effect of vapor lock on root canal debridement by using a side-vented needle for positive-pressure irrigant delivery. J Endod. 2010 Apr;36(4):745-50. Pubmed PMID: 20307757

[56]. Neelakantan P, Devaraj S, Jagannathan N. Histologic Assessment of Debridement of the Root Canal Isthmus of Mandibular Molars by Irrigant Activation Techniques Ex Vivo. J Endod. 2016 Aug;42(8):1268-72. Pubmed PMID: 27339632

[57]. Roy RA, Ahmad M, Crum LA. Physical mechanisms governing the hydrodynamic response of an oscillating ultrasonic file. Int Endod J. 1994 Jul;27(4):197-207. Pubmed PMID: 7814129.
[58]. Plotino G, Pameijer CH, Grande NM, Somma F. Ultrasonics in endodontics: a review of the literature. Journal of endodontics. 2007 Feb 1;33(2):8195.

[59]. Dioguardi M, Di Gioia G, Illuzzi G, Ciavarella D, Laneve E, Troiano G, et al. Passive Ultrasonic Irrigation Efficacy in the Vapor Lock Removal: Systematic Review and Meta-Analysis. ScientificWorldJournal. 2019 Mar 12;2019:6765349. Pubmed PMID: 30992694.

[60]. Nagendrababu V, Jayaraman J, Suresh A, Kalyanasundaram S, Neelakan$\tan$ P. Effectiveness of ultrasonically activated irrigation on root canal disinfection: a systematic review of in vitro studies. Clin Oral Investig. 2018 Mar;22(2):655-670. Pubmed PMID: 29372445.

[61]. Middha M, Sangwan P, Tewari S, Duhan J. Effect of continuous ultrasonic irrigation on postoperative pain in mandibular molars with nonvital pulps: a randomized clinical trial. Int Endod J. 2017 Jun;50(6):522-530. Pubmed PMID: 27248848.

[62]. Gündoğar M, Sezgin GP, Kaplan SS, Özyürek H, Uslu G, Özyürek T. Postoperative pain after different irrigation activation techniques: a randomized, clinical trial. Odontology. 2021 Apr;109(2):385-392. Pubmed PMID: 32915346.

[63]. Ishizaki NT, Matsumoto K, Kimura Y, Wang X, Kinoshita J, Okano SM, et al. Thermographical and morphological studies of Er,Cr:YSGG laser irradiation on root canal walls. Photomed Laser Surg. 2004 Aug;22(4):291-7. Pubmed PMID: 15345170.

[64]. Olivi G. Laser use in endodontics: evolution from direct laser irradiation to laser-activated irrigation. J Laser Dent. 2013;21(2):58-71.

[65]. Yamazaki R, Goya C, Yu DG, Kimura Y, Matsumoto K. Effects of erbium,chromium:YSGG laser irradiation on root canal walls: a scanning electron microscopic and thermographic study. J Endod. 2001 Jan;27(1):912. Pubmed PMID: 11487170.

[66]. Jaramillo DE. Irrigation of the root canal system by laser activation (LAI): PIPS photon-induced photoacoustic streaming. InEndodontic Irrigation 2015 (pp. 227-235). Springer, Cham.

[67]. Peters OA, Bardsley S, Fong J, Pandher G, Divito E. Disinfection of root canals with photon-initiated photoacoustic streaming. J Endod. 2011 Jul;37(7):1008-12. Pubmed PMID: 21689561.

[68]. Lukac N, Muc BT, Jezersek M, Lukac M. Photoacoustic endodontics using the novel SWEEPS Er: YAG laser modality. J Laser Health Acad. 2017;1:17 .

[69]. Arıcıoğlu B, Çıkman AŞ, Babacan M. The comparison of cleaning efficacy and apical extrusion of advanced irrigation activation methods with a novel Er: YAG laser modality: sweeps. Lasers in Dental Science. 2021 Mar;5(1):43-52.

[70]. Wang XN, Shi J. Shock wave-enhanced emission photoacoustic streaming versus photon-induced photoacoustic streaming modes for clearing root canal bacteria using erbium-doped yttrium aluminum garnet lasers: An in vitro study.

[71]. Gordon W, Atabakhsh VA, Meza F, Doms A, Nissan R, Rizoiu I, et al. The antimicrobial efficacy of the erbium, chromium:yttrium-scandium-galliumgarnet laser with radial emitting tips on root canal dentin walls infected with Enterococcus faecalis. J Am Dent Assoc. 2007 Jul;138(7):992-1002. Pubmed PMID: 17606499.

[72]. DiVito EE, Colonna MP, Olivi G. The photoacoustic efficacy of an Er: YAG laser with radial and stripped tips on root canal dentin walls: an SEM evaluation. J Laser Dent. 2011;19(1):156-61.

[73]. Jaramillo DE, Aguilar E, Arias A, Ordinola-Zapata R, Aprecio RM, Ibarrola JL. Root canal disinfection comparing conventional irrigation vs photoninduced photoacoustic streaming (PIPS) using a buffered $0.5 \%$ sodium hypochlorite solution. Evidence-Based Endodontics. 2016 Dec;1(1):1-5.

[74]. Kosarieh E, Bolhari B, Sanjari Pirayvatlou S, Kharazifard MJ, Sattari Khavas $S$, Jafarnia S, et al. Effect of Er:YAG laser irradiation using SWEEPS and PIPS technique on dye penetration depth after root canal preparation. Photodiagnosis Photodyn Ther. 2021 Mar;33:102136. Pubmed PMID: 33307236.

[75]. Vidas J, Snjaric D, Braut A, Carija Z, Persic Bukmir R, De Moor RJG, et al. Comparison of apical irrigant solution extrusion among conventional and laser-activated endodontic irrigation. Lasers Med Sci. 2020 Feb;35(1):205211. Pubmed PMID: 31321596.

[76]. Mandras N, Pasqualini D, Roana J, Tullio V, Banche G, Gianello E, et al. Influence of Photon-Induced Photoacoustic Streaming (PIPS) on Root Canal Disinfection and Post-Operative Pain: A Randomized Clinical Trial. J Clin Med. 2020 Dec 2;9(12):3915. Pubmed PMID: 33276670.

[77]. Morsy DA, Negm M, Diab A, Ahmed G. Postoperative pain and antibacterial effect of $980 \mathrm{~nm}$ diode laser versus conventional endodontic treatment in necrotic teeth with chronic periapical lesions: A randomized control trial. F1000Res. 2018 Nov 15;7:1795. Pubmed PMID: 31372210.

[78]. Liapis D, De Bruyne MAA, De Moor RJG, Meire MA. Postoperative pain after ultrasonically and laser-activated irrigation during root canal treatment: 
a randomized clinical trial. Int Endod J. 2021 Feb 17. Pubmed PMID: 33595920 .

[79]. Coelho MS, Vilas-Boas L, Tawil PZ. The effects of photodynamic therapy on postoperative pain in teeth with necrotic pulps. Photodiagnosis Photodyn Ther. 2019 Sep;27:396-401. Pubmed PMID: 31301436.

[80]. Gulabivala K, Ng YL, Gilbertson M, Eames I. The fluid mechanics of root canal irrigation. Physiol Meas. 2010 Dec;31(12):R49-84. Pubmed PMID: 21071831

[81]. Susila A, Minu J. Activated Irrigation vs. Conventional non-activated Irrigation in Endodontics - A Systematic Review. Eur Endod J. 2019 Nov 25;4(3):96-110. Pubmed PMID: 32161895.

[82]. Vijayashree Priyadharsini J. In silico validation of the non-antibiotic drugs acetaminophen and ibuprofen as antibacterial agents against red complex pathogens. J Periodontol. 2019 Dec;90(12):1441-1448. Pubmed PMID: 31257588 .

[83]. J PC, Marimuthu T, C K, Devadoss P, Kumar SM. Prevalence and measurement of anterior loop of the mandibular canal using CBCT: A cross sectional study. Clin Implant Dent Relat Res. 2018 Aug;20(4):531-534. Pubmed PMID: 29624863

[84]. Ramesh A, Varghese S, Jayakumar ND, Malaiappan S. Comparative estimation of sulfiredoxin levels between chronic periodontitis and healthy patients - A case-control study. J Periodontol. 2018 Oct;89(10):1241-1248. Pubmed PMID: 30044495 .

[85]. Ramadurai N, Gurunathan D, Samuel AV, Subramanian E, Rodrigues SJL. Effectiveness of 2\% Articaine as an anesthetic agent in children: randomized controlled trial. Clin Oral Investig. 2019 Sep;23(9):3543-3550. Pubmed PMID: 30552590 .
[86]. Sridharan G, Ramani P, Patankar S, Vijayaraghavan R. Evaluation of salivary metabolomics in oral leukoplakia and oral squamous cell carcinoma. J Oral Pathol Med. 2019 Apr;48(4):299-306. Pubmed PMID: 30714209.

[87]. Mathew MG, Samuel SR, Soni AJ, Roopa KB. Evaluation of adhesion of Streptococcus mutans, plaque accumulation on zirconia and stainless steel crowns, and surrounding gingival inflammation in primary molars: randomized controlled trial. Clin Oral Investig. 2020 Sep;24(9):3275-3280. Pubmed PMID: 31955271.

[88]. Samuel SR. Can 5-year-olds sensibly self-report the impact of developmental enamel defects on their quality of life? Int J Paediatr Dent. 2021 Mar;31(2):285-286. Pubmed PMID: 32416620.

[89]. R H, Ramani P, Ramanathan A, R JM, S G, Ramasubramanian A, et al. CYP2 C9 polymorphism among patients with oral squamous cell carcinoma and its role in altering the metabolism of benzo[a]pyrene. Oral Surg Oral Med Oral Pathol Oral Radiol. 2020 Sep;130(3):306-312. Pubmed PMID: 32773350.

[90]. Chandrasekar R, Chandrasekhar S, Sundari KKS, Ravi P. Development and validation of a formula for objective assessment of cervical vertebral bone age. Prog Orthod. 2020 Oct 12;21(1):38. Pubmed PMID: 33043408.

[91]. Vijayashree Priyadharsini J, Smiline Girija AS, Paramasivam A. In silico analysis of virulence genes in an emerging dental pathogen A. baumannii and related species. Arch Oral Biol. 2018 Oct;94:93-98. Pubmed PMID: 30015217. 